\title{
Reactivity of Ir-NSiN Complexes: Ir-Catalyzed Dehydrogenative Silylation of Carboxylic Acids
}

\author{
Alejandro Julián, ${ }^{[a]}$ Karin Garcés, ${ }^{[a]}$ Ralte Lalrempuia, ${ }^{[a][b]}$ E. A. Jaseer,${ }^{[c]}$ Pilar García-Orduña, ${ }^{[a]}$ \\ Francisco J. Fernández-Alvarez, ${ }^{\left[{ }^{[a]}\right]}$ Fernando J. Lahoz, ${ }^{[a]}$ and Luis A. Oro*[a][c]
}

\begin{abstract}
This work describes the results from the studies on the potential of $[\operatorname{Ir}(\mu-\mathrm{Cl})(\operatorname{cod})]_{2}(\operatorname{cod}=1,5$-cyclooctadiene $)$ as metallic precursor for the preparation of $\operatorname{Ir}(\mathrm{NSiN})$ complexes $(\mathrm{NSiN}=$ fac-bis(pyridine-2-yloxy)methylsilyl). It is noteworthy that the reaction of $[\operatorname{Ir}(\mu-\mathrm{Cl})(\operatorname{cod})]_{2}$ with bis-(pyridine-2-yloxy)methylsilane has allowed the synthesis of $\left[\operatorname{lr}(\mathrm{H})(\mathrm{Cl})(\mathrm{NSiN})\left(\eta^{2}-\mathrm{Cod}\right)\right]$ with an uncommon $\eta^{2}-$ coordination mode for the cod ligand. Moreover, the application of Ir$\mathrm{NSiN}$ species as catalysts precursors for the dehydrogenative silylation of carboxylic acids has also been explored. The outcomes from these catalytic studies revealed a clear influence of the ancillary ligand on the catalytic activity of Ir-NSiN species. Thus, while $\left[\operatorname{lr}(\mathrm{H})\left(\mathrm{CF}_{3} \mathrm{SO}_{3}\right)(\mathrm{NSiN})(\mathrm{coe})\right]$ shows a poor catalytic activity, the related complex $\left[\mathrm{Ir}(\mathrm{H})\left(\mathrm{CF}_{3} \mathrm{CO}_{2}\right)(\mathrm{NSiN})(\mathrm{coe})\right]$ with a trifluoroacetate ligand has demonstrated to be a highly active catalyst precursor.
\end{abstract}

$\mathrm{HSiMe}\left(\mathrm{OSiMe}_{3}\right)_{2}{ }^{[13,14]}$ has been observed. These outcomes stimulated us to study the potential of Ir-NSiN species as catalyst precursors for the reduction of carboxylic acids with $\mathrm{HSiMe}\left(\mathrm{OSiMe}_{3}\right)_{2}$.

\section{Results and Discussion}

Synthesis and reactivity of Ir-NSiN complexes. Ir-NSiN species $(\mathrm{NSiN}=$ fac-bis-(pyridine-2-yloxy)methylsilyl, or fac-bis(4-methylpyridine-2-yloxy)methylsilyl $)^{[7]}$ have been so far prepared using $\left[\operatorname{Ir}(\mu-\mathrm{Cl})(\mathrm{coe})_{2}\right]_{2}$ (coe = cis-cyclooctene) as metallic precursor. This work shows that $[\operatorname{lr}(\mu-\mathrm{Cl})(\operatorname{cod})]_{2}(\operatorname{cod}=$ 1,5-cyclooctadiene) could also be used as metallic precursor for the preparation of Ir-NSiN species.

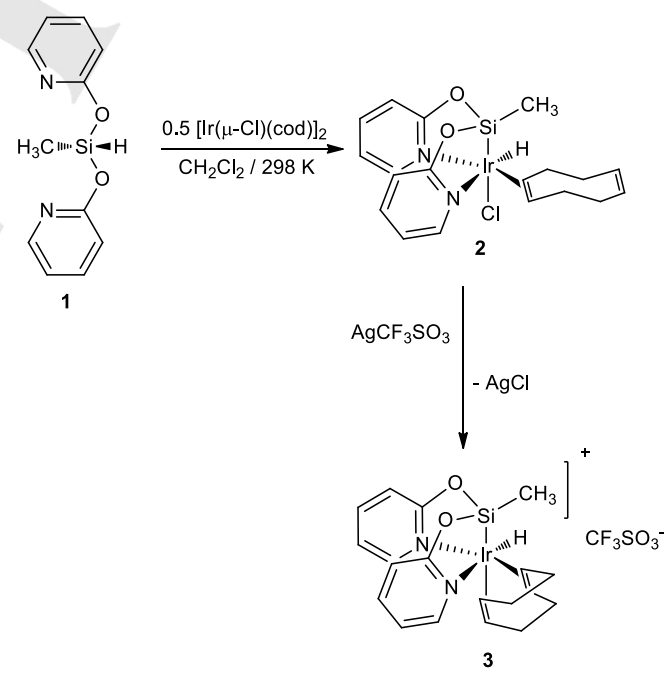

Scheme 1. Preparation of Ir-NSiN complexes with 1,5-cyclooctadiene.

The treatment of $[\operatorname{Ir}(\mu-\mathrm{Cl})(\operatorname{cod})]_{2} \quad$ with bis-(pyridine-2yloxy)methylsilane (1) in $\mathrm{CH}_{2} \mathrm{Cl}_{2}$ quantitatively leads to the iridium(III) complex $\left[\mathrm{Ir}(\mathrm{H})(\mathrm{Cl})(\mathrm{NSiN})\left(\eta^{2}-\mathrm{cod}\right)\right](2)$, which has been isolated as a white solid in $87 \%$ yield (Scheme 1). The Ir-NSiN species 2 has been fully characterized by elemental analysis, mass spectrometry and NMR spectroscopy. In addition, the $\eta^{2}$ coordination mode of the cod ligand to the iridium atom in $\mathbf{2}$ has been confirmed by X-ray diffraction studies (Figure 1). 


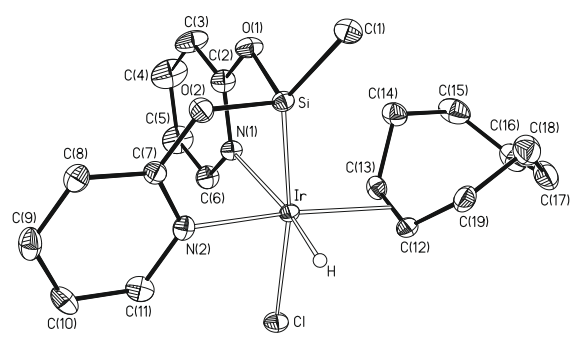

Figure 1. Molecular structure of complex 2. Selected bond lengths $(\AA)$ and angles $\left({ }^{\circ}\right)$ for compound 2. Ir-Si, 2.2356(12); Ir-Cl, 2.5229(10); Ir-Ct ${ }^{[\mathrm{a}]}$ 2.068(4); Ir-N1, 2.197(3); Ir-N2, 2.114(4); Ir-H, 1.53(7); Si-Ir-Cl, 170.51(4); SiIr-Ct ${ }^{[a]}, 100.47(13)$; Si-Ir-N1, 79.93(9); Si-Ir-N2, 80.60(11); Si-Ir-H, 96(2); Cl-Ir$\mathrm{Ct}^{[\mathrm{al}}$, 86.29(13); Cl-Ir-N1, 92.26(9); Cl-Ir-N2, 93.61(10); Cl-Ir-H, 90(2); $\mathrm{Ct}^{[\mathrm{a}]}-\mathrm{Ir}-$ N1, 101.58(15); Ct ${ }^{[a]}-\mathrm{Ir}-\mathrm{N} 2$, 172.08(15); Ct ${ }^{[\mathrm{a}]}-\mathrm{Ir}-\mathrm{H}, 89(2) ; \mathrm{N} 1-\mathrm{Ir}-\mathrm{N} 2 ; 86.34(13)$; $\mathrm{N} 1-\mathrm{Ir}-\mathrm{H}, 169(2) ; \mathrm{N} 2-\mathrm{Ir}-\mathrm{H}, 83(2) .{ }^{\text {[a] }} \mathrm{Ct}$ represents the centroid of the $\mathrm{C} 12=\mathrm{C} 13$ olefinic bond in compound 2.

The NSiN ligand in $\mathbf{2}$ is facially coordinated to the iridium center. Si-Ir-N cis angles (Si-Ir-N1, 79.93(9) ${ }^{\circ}$ and Si-Ir-N2, 80.60(11) ${ }^{\circ}$ ) are deviated from the ideal value of $90^{\circ}$ due to the NSiN chelating bonding through the formation of two Ir-Si-O-C-N metallacycles, with ring puckering parameters (Ir-Si-O1-C2-N1: $q=0.148(2) \AA, \varphi=29.6(15)^{\circ}$, Ir-Si-O2-C7-N2: $q=0.135(2) \AA, \varphi=-$ $141.0(15))^{[15]}$ typical of envelope $E_{2}$ and ${ }^{2} E$ enantiomorphic configurations. The pyridine- $\mathrm{N}$ atoms are located trans to the hydride and to the $\eta^{2}$-cyclooctadiene ligands. The Ir-N1 bond length $(2.197(3) \AA)$ is longer than Ir-N2 (2.114(4) $\AA$ ), most likely associated to the high structural trans effect of the hydride ligand compared to that exerted by the olefin. The chloride ligand ( $\mathrm{Ir}-\mathrm{Cl}$, $2.5229(10) \AA$ ) is coordinated trans to the $\mathrm{Si}$ atom. Structural parameters describing the metal coordination sphere are close to those reported in related $\mathrm{Rh}$ and $\mathrm{Ir}-(\mathrm{NSiN})$ metal complexes. ${ }^{[8,10,13,14]}$

The coordination mode of the cod fragment to the metal in compound 2 deserves special attention. The bond length found between the metal atom and the olefin in compound $2(2.068(4)$ $\AA)$ is similar to those observed in related $\operatorname{Ir}(\mathrm{NSiN})\left(\eta^{2}-\mathrm{coe}\right)$ complexes (in the range 2.062(12)-2.102(2) $\AA$ ). ${ }^{[8,13,14]}$ Although the versatility of cyclooctadiene ligand to coordinate to iridium in different forms has been well established, ${ }^{[16]}$ it tends to chelate to the metal in a $\eta^{4}$ coordination mode. It should be mentioned that the equilibrium between $\operatorname{Ir}\left(\eta^{2}\right.$-cod $)$ and $\operatorname{Ir}\left(\eta^{4}\right.$-cod $)$ has been proposed as key step in some catalytic processes. ${ }^{[17]}$ In addition, to the best of our knowledge only three mononuclear complexes containing an $\operatorname{Ir}\left(\eta^{2}\right.$-cod) fragment have been crystallographically characterized: $\quad\left[\left(\eta^{5}-\mathrm{Cp}\right) \operatorname{Ir}\left(\eta^{2}-\mathrm{cod}\right)(\mathrm{NHC})\right]^{[18]}, \quad\left[\left(\eta^{5}-\mathrm{Cp}\right) \operatorname{Ir}\left(\eta^{2}-\right.\right.$ cod) $($ biph $)]^{[19]}$ and $\left[\operatorname{Ir}\left(\eta^{2}-\operatorname{cod}\right)(4-\mathrm{Ph}) \operatorname{Tr}\left(\mathrm{NP}\left({ }^{(} \mathrm{Pr}\right)_{2}\right)\left(\mathrm{NHP}\left({ }^{(} \mathrm{Pr}\right)_{2}\right)\right] .^{[20]}$ The coordinated olefinic bond length in compound 2 (C12=C13: $1.411(6) \AA$ ) has been found to be longer than that of the uncoordinated one $(C 16=C 17: 1.334(9) \AA)$, a feature that has been related to a $\pi$-back donation from the metal atom. ${ }^{[18,19]}$

The ${ }^{1} \mathrm{H}$ and ${ }^{13} \mathrm{C}\left\{{ }^{1} \mathrm{H}\right\}$ NMR spectra of 2 in $\mathrm{CD}_{2} \mathrm{Cl}_{2}$ support the $\eta^{2}$ coordination of the cod ligand in solution. Thus, the ${ }^{1} \mathrm{H}$ NMR spectra of 2 exhibit one multiplet resonance between $\delta 5.67$ and $5.51 \mathrm{ppm}$, assigned to the two $\mathrm{Csp}^{2}-\mathrm{H}$ protons of the free olefinic moiety of the cyclooctadiene ligand, which show correlation in the heteronuclear single quantum correlation (HSQC) spectra with two resonances which appear at $\delta 130.2$ and $130.1 \mathrm{ppm}$, respectively, in the ${ }^{13} \mathrm{C}\left\{{ }^{1} \mathrm{H}\right\}$ NMR spectra of 2 . It should be mentioned that ${ }^{13} \mathrm{C}\left\{{ }^{1} \mathrm{H}\right\}$ NMR spectra of free 1,5-cyclooctadiene show the olefinic carbon atoms around $\delta 129 \mathrm{ppm}$. As it should be expected, the carbon atoms of the coordinated olefinic fragment appear shifted at higher field at $\delta 68.7$ and $65.9 \mathrm{ppm}$, respectively. The ${ }^{1} \mathrm{H}$ NMR spectra of species 2 in $\mathrm{CD}_{2} \mathrm{Cl}_{2}$ also show a singlet resonance corresponding to the hydride ligand at $\delta-15.35 \mathrm{ppm}$, which is in the same range of that observed for related species $[\mathrm{Ir}(\mathrm{H})(\mathrm{Cl})(\mathrm{NSiN})(\mathrm{Coe})](\mathbf{4})^{[8]}$ with a cyclooctene instead of the cyclooctadiene ligand. The ${ }^{29} \mathrm{Si}\left\{{ }^{1} \mathrm{H}\right\}$ NMR spectra of 2 in $\mathrm{CD}_{2} \mathrm{Cl}_{2}$ exhibit a singlet at $\delta 31.3 \mathrm{ppm}$, which compares well with the corresponding resonances reported for 4 . Compound 2 reacts with one equivalent of silver trifluoromethanesulfonate in $\mathrm{CH}_{2} \mathrm{Cl}_{2}$, in the absence of light, to give a light-orange solid, which has been fully characterized by means of elemental analysis, mass spectrometry and NMR spectroscopy as the ionic iridium(III) species 3 (Scheme 1).

${ }^{1} \mathrm{H}$ NMR studies of the reaction of 2 with $\mathrm{PCy}_{3}$ in $\mathrm{C}_{6} \mathrm{D}_{6}$ show the resonances due to free cyclooctadiene together with those corresponding to the complex $\left[\operatorname{lr}(\mathrm{H})(\mathrm{Cl})(\mathrm{NSiN})\left(\mathrm{PCy}_{3}\right)\right]$ (5). It should be mentioned that analogous behavior was observed when using complex 4 instead of 2 (Scheme 2). In addition, when the reactions of $\mathbf{2}$ (or $\mathbf{4}$ ) with one equivalent of $\mathrm{PCy}_{3}$ were carried out at preparative level, the corresponding phosphane derivative $\left[\mathrm{Ir}(\mathrm{H})(\mathrm{Cl})(\mathrm{NSiN})\left(\mathrm{PCy}_{3}\right)\right](\mathbf{5})$ was obtained in high yield. The reaction of complex 5 with $\mathrm{AgCF}_{3} \mathrm{SO}_{3}$ quantitatively gives the triflate derivative $\left[\operatorname{Ir}(\mathrm{H})\left(\mathrm{CF}_{3} \mathrm{SO}_{3}\right)(\mathrm{NSiN})\left(\mathrm{PCy}_{3}\right)\right]$ (6) (Scheme $2)$. The triflate derivatives 3 or $\left[\operatorname{Ir}(\mathrm{H})\left(\mathrm{CF}_{3} \mathrm{SO}_{3}\right)(\mathrm{NSiN})(\mathrm{coe})\right](7)^{[13]}$ also reacts with one equivalent of $\mathrm{PCy}_{3}$ to afford complex 6 . However, this methodology allows the formation of other minor reaction side products, corresponding to the coordination of two phosphane ligands to the iridium atom.

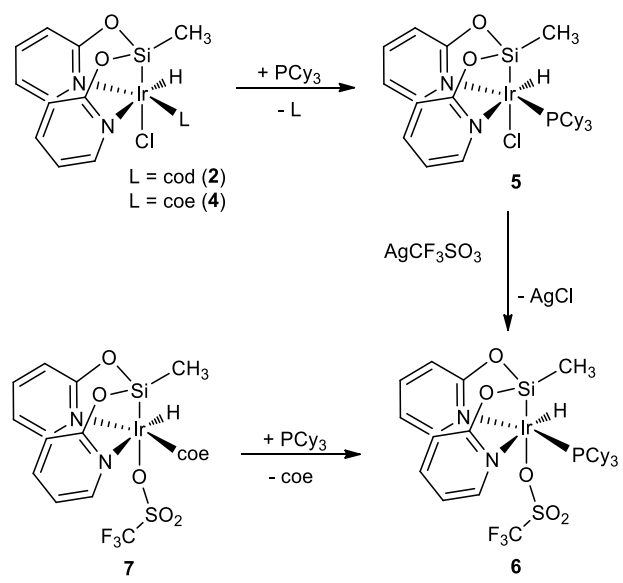

Scheme 2. Synthesis of Ir-NSiN phosphane complexes.

The Ir-NSiN derivatives $\mathbf{5}$ and $\mathbf{6}$ have been fully characterized. Moreover, the solid state structure of $\mathbf{5}$ has been determined by $\mathrm{X}$-ray diffraction studies (Figure 2). 


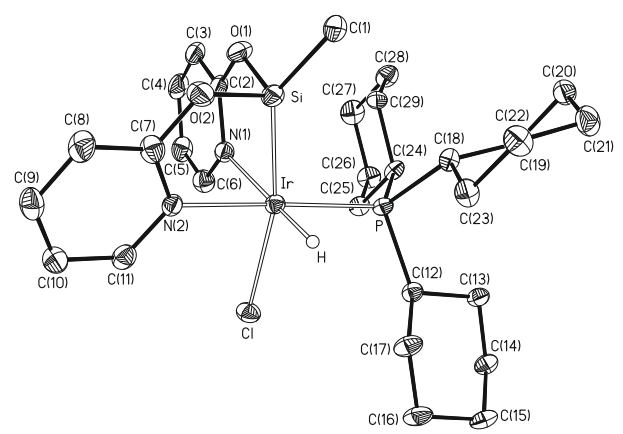

Figure 2. Molecular structure of complex 5. Selected bond lengths $(\AA)$ and angles $\left({ }^{\circ}\right)$ for compound 5 . Ir-Si, 2.2243(13); Ir-Cl, 2.5099(11); Ir-P, 2.2763(11); Ir-N1, 2.204(4); Ir-N2, 2.172(3); Ir-H, 1.641(10); Si-Ir-Cl, 166.07(4); Si-Ir-P, 99.22(4); Si-Ir-N1, 80.14(10); Si-Ir-N2, 79.07(10); Si-Ir-H, 95.0(18); ClIr-P, 92.83(4); Cl-Ir-N1, 90.39(10); Cl-Ir-N2, 90.13(10); Cl-Ir-H, 93.8(18); P-IrN1, 103.01(10); P-Ir-N2, 170.78(10); P-Ir-H, 80.7(18); N1-Ir-N2, 85.69(13); N1Ir-H, 174.2(18), N2-Ir-H, 90.4(18)

The iridium atom in $\mathbf{5}$ displays slightly distorted octahedral coordination geometry (Figure 2) with similar structural features than those found in its rhodium analogous. ${ }^{[10]}$ The NSiN ligand is facially coordinated to the iridium center, exhibiting Si-Ir-N cis angles deviated from the ideal value of $90^{\circ}$ due to the chelating bonding of the ligand. Ring puckering parameters of the iridacycles (Ir-Si-O1-C2-N1: $q=0.094(3) \AA, \varphi=11(3)^{\circ}$, Ir-Si-O2C7-N2: $q=0.210(3) \AA, \varphi=-156.4(10))$ characterize their twisted ${ }^{1} \mathrm{~T}_{2}$ and ${ }^{2} \mathrm{~T}_{1}$ (with an envelope ${ }^{2} \mathrm{E}$ contribution) conformations. The Ir-Si bond lenght $(2.2243(13) \AA$ ) is shorter than that found in complex 2, and indeed, it is in the lower limit of an iridium-silyl mononuclear species $(2.22-2.42 \AA) .{ }^{[21]}$ The nitrogen atoms are located trans to the hydride and the phosphane ligands, and although their different trans effect is reflected in the Ir- $\mathrm{N}$ bond lengths, the disparity between Ir-N1 and Ir-N2 bond lengths in complex $\mathbf{5}$ is less marked than that observed in compound $\mathbf{2}$. The coordination sphere is completed by a chloride ligand. Interestingly, the Ir-Cl bond length in $\mathbf{5}$ is shorter $(2.5099(11) \AA$ ) than that found for compound 2 . This feature may be due to the different intermolecular hydrogen bond patterns involving chlorine atom in each structure $\left(R_{2}^{2}(10)\right.$ in compound 2 and $\mathrm{C}(7)$, $R_{2}^{2}(12)$ and $R_{2}^{2}(14)$ in compound 5) (see SI).

Study of the Ir-NSiN catalyzed reaction of carboxylics acids with silanes. The formation of the silylether $\mathrm{CF}_{3} \mathrm{CH}_{2} \mathrm{OSiMe}\left(\mathrm{OSiMe}_{3}\right)_{2}$ during the hydrosilylation of $\mathrm{CO}_{2}$ with $\mathrm{HSiMe}\left(\mathrm{OSiMe}_{3}\right)_{2}$ using complex $\left[\mathrm{Ir}(\mathrm{H})\left(\mathrm{CF}_{3} \mathrm{CO}_{2}\right)(\mathrm{NSiN})(\mathrm{Coe})\right](8)$ as catalyst precursor has been recently reported (Scheme 3$).{ }^{[14]}$ This evidence prompted us to study the potential of Ir-NSiN species as catalysts for the reduction of carboxylic acids using $\mathrm{HSiMe}\left(\mathrm{OSiMe}_{3}\right)_{2}$ as reducing agent.

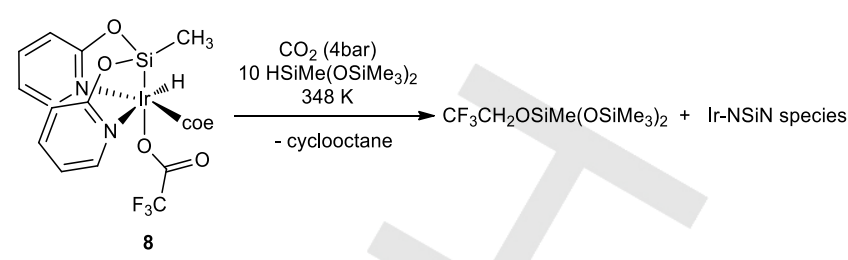

Scheme 3. Reduction of the ancillary trifluroacetate ligand in 8 to give $\mathrm{CF}_{3} \mathrm{CH}_{2} \mathrm{OSiMe}\left(\mathrm{OSiMe}_{3}\right)_{2}$ during the 8-catalyzed hydrosilylation of $\mathrm{CO}_{2}$ with $\mathrm{HSiMe}\left(\mathrm{OSiMe}_{3}\right)_{2} \cdot{ }^{[14]}$

${ }^{1} \mathrm{H}$ NMR studies of the reaction of $\mathrm{ECOOH}\left(\mathrm{E}=\mathrm{H}, \mathrm{CH}_{3}, \mathrm{Ph}\right)$ with one equivalent of $\mathrm{HSiMe}\left(\mathrm{OSiMe}_{3}\right)_{2}$ in $\mathrm{C}_{6} \mathrm{D}_{6}$ at $328 \mathrm{~K}$ in presence of catalytic amounts of complexes $\mathbf{7}$ or $\mathbf{8}$ show a clear influence of the ancillary ligands on the performance of the resulting catalytic system (Table 1). Thus, while using complex 8 as catalyst, it is possible to achieve the quantitative conversion of the parent carboxylic acids into the corresponding silylester in less than 4 hours, the related triflate derivatives 6 and 7 have shown a poorer catalytic activity (Table 1). It should be mentioned that the phosphane complex 6 is slightly more active than 7 but less than 8 (Table 1).

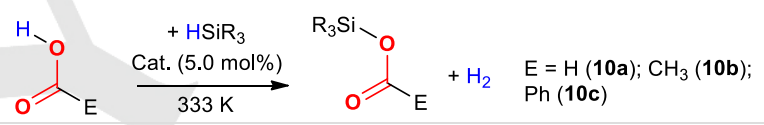

Table 1. Reaction products from the reaction of carboxylic acids with one equivalent of $\mathrm{HSiMe}\left(\mathrm{OSiMe}_{3}\right)_{2}$ in presence of catalytic amounts $(5.0 \mathrm{~mol} \%)$ of Ir-NSiN complexes in $\mathrm{C}_{6} \mathrm{D}_{6}$.

\begin{tabular}{cccc}
\hline Acid & catalyst & $\mathrm{T}(\mathrm{K})$ & Silyl ester(\% $)^{[\mathrm{a}][\mathrm{b}]}$ \\
\hline $\mathrm{HCOOH}$ & $\mathbf{6}$ & 328 & $10 \mathrm{a}(63.7)$ \\
$\mathrm{HCOOH}$ & 7 & 328 & $10 \mathrm{a}(52.0)$ \\
$\mathrm{HCOOH}$ & 8 & 328 & $10 \mathrm{a}(95.0)$ \\
$\mathrm{CH}_{3} \mathrm{COOH}$ & 7 & 328 & $10 \mathrm{~b}(43.5)$ \\
$\mathrm{CH}_{3} \mathrm{COOH}$ & 8 & 328 & $10 \mathrm{~b}(84.5)$ \\
$\mathrm{PhCOOH}^{\mathrm{Ph}}$ & 7 & 328 & $10 \mathrm{c}(65.0)$ \\
$\mathrm{PhCOOH}$ & 8 & 328 & $10 \mathrm{c}(90.0)$ \\
\hline
\end{tabular}

[a] \% calculated by ${ }^{1} \mathrm{H}$ NMR integration using hexamethylbenzene $(0.07$ $\mathrm{mmol}$ ) as internal standard. [b] Data corresponding to the ${ }^{1} \mathrm{H}$ NMR spectra registered after $3.5 \mathrm{~h}$ of reaction.

The silylester species $10 \mathrm{a}-\mathrm{c}$ were characterized by comparison of their ${ }^{1} \mathrm{H},{ }^{13} \mathrm{C}$ and ${ }^{29} \mathrm{Si}$ NMR spectra with the reported data (Figures S1 to S6). ${ }^{[8,14,4 \mathrm{e}]}$ In this context, it should be mentioned that few catalytic systems effective for the selective dehydrogenative silylation of carboxylic acids with silanes have been reported so far. ${ }^{[4]}$ It is worth noting that ${ }^{1} \mathrm{H}$ NMR studies of the 8-catalyzed reactions of formic, acetic or benzoic acid, with 3.0 equivalents of $\mathrm{HSiMe}\left(\mathrm{OSiMe}_{3}\right)_{2}$ in $\mathrm{C}_{6} \mathrm{D}_{6}$ at $328 \mathrm{~K}$ showed that, after $24 \mathrm{~h}$, the corresponding silylester species 10 remains 
as the major reaction product and no evidence of its reduction was observed.

Kinetic studies of the reaction of $\mathrm{ECOOH}\left(\mathrm{E}=\mathrm{H}, \mathrm{CH}_{3}, \mathrm{Ph}\right)$ with $\mathrm{HSiMe}\left(\mathrm{OSiMe}_{3}\right)_{2}$ in presence of $8(1.0 \mathrm{~mol} \%)$ using dry-toluene as solvent were carried out in a micro-reactor. ${ }^{[22]}$ This allowed measuring the hydrogen pressure generated during the process (Figure 3). As a result from these studies a turnover frequency number at $50 \%$ conversion $\left(\mathrm{TOF}_{1 / 2}\right.$ ) value of 195,2000 and 136 $\mathrm{h}^{-1}$ were found for the $\mathrm{H}_{2}$ generation from the dehydrogenative Si-O coupling of $\mathrm{HSiMe}\left(\mathrm{OSiMe}_{3}\right)_{2}$ with formic, acetic and benzoic acid, respectively. Therefore, the dehydrogenative silylation is faster for acetic acid. However, in agreement with the NMR experiments (Table 1) the reaction yield has found to be lower for $\mathrm{CH}_{3} \mathrm{COOH}$ than for $\mathrm{HCOOH}$ and $\mathrm{PhCOOH}$. These data showed that the Ir-NSiN based catalytic system for dehydrogenative silylation of carboxylic acids could be considered as one of the most active so far reported. ${ }^{4}$

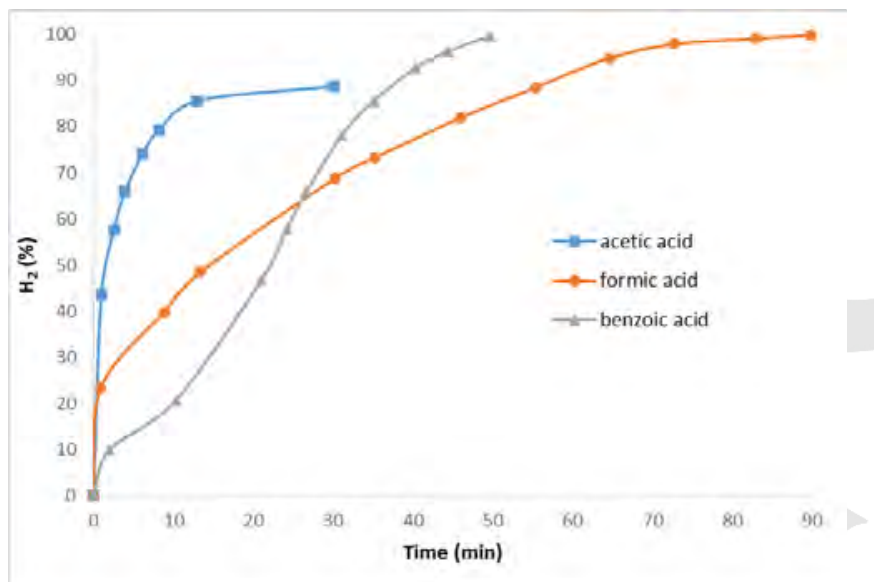

Figure 3. Hydrogen generation (\% related to $1.0 \mathrm{mmol}$ as $100 \%$ ) versus time (min) for the catalytic dehydrogenative Si-O coupling of acetic acid, formic acid and benzoic acid $(1.0 \mathrm{mmol})$ with $\mathrm{HSiMe}\left(\mathrm{OSiMe}_{3}\right)_{2}(1.01 \mathrm{mmol})$ using $8(1.0$ $\mathrm{mol} \%)$ as catalyst in dry toluene $(1.0 \mathrm{~mL})$ at $328 \mathrm{~K}$.

${ }^{1} \mathrm{H}$ and ${ }^{29} \mathrm{Si}\left\{{ }^{1} \mathrm{H}\right\}$ NMR studies of the 8-catalyzed reaction of $\mathrm{CF}_{3} \mathrm{COOH}$ with $\mathrm{HSiMe}\left(\mathrm{OSiMe}_{3}\right)_{2}$ under the same conditions as above described for others acids evidenced the formation of molecular hydrogen together with a mixture of unidentified species (Table 2). ${ }^{29} \mathrm{Si}\left\{{ }^{1} \mathrm{H}\right\}$ NMR spectra of the final reaction product show that the intensity of the resonances assigned to $\mathrm{CF}_{3} \mathrm{COOSiMe}\left(\mathrm{OSiMe}_{3}\right)_{2}(\mathbf{1 0 d})(\delta 8.5 \text { and }-65.2 \mathrm{ppm})^{[4 \mathrm{e}]}$ is very low in comparison with the intensity of the resonances corresponding to others not identified species (Figure S7). In addition, no evidence of $\left\{\mathrm{SiMe}\left(\mathrm{OSiMe}_{3}\right)_{2}\right\}_{2} \mathrm{O}$ nor residual $\mathrm{CF}_{3} \mathrm{COOH}$ were observed in the ${ }^{29} \mathrm{Si}\left\{{ }^{1} \mathrm{H}\right\}$ and ${ }^{13} \mathrm{C}\left\{{ }^{1} \mathrm{H}\right\}$ NMR spectra, respectively. The ${ }^{13} \mathrm{C}\left\{{ }^{1} \mathrm{H}\right\}$ NMR spectra of these reaction samples show the presence of two quartet resonances centered at $\delta 156.8 \mathrm{ppm}\left({ }^{2} J_{\mathrm{C}-\mathrm{F}}=42.1 \mathrm{~Hz}\right)$ and $\delta 155.6 \mathrm{ppm}\left({ }^{2} J_{\mathrm{C}-\mathrm{F}}=42.6\right.$ $\mathrm{Hz}$ ), high field shifted with respect to the corresponding resonance for $\mathrm{CF}_{3} \mathrm{COOH}\left(\delta 160.8 \mathrm{ppm},{ }^{2} \mathrm{~J}_{\mathrm{C}-\mathrm{F}}=43.8 \mathrm{~Hz}\right.$ ) (Figure S8). These spectra showed another two quartet resonances due $\mathrm{CF}_{3}$ groups $\left(\delta 115.32 \mathrm{ppm},{ }^{1} \mathrm{~J}_{\mathrm{C}-\mathrm{F}}=286.2 \mathrm{~Hz}\right.$ and $\delta 115.30 \mathrm{ppm}$,
${ }^{1} J_{\mathrm{C}-\mathrm{F}}=286.0 \mathrm{~Hz}$ ) that are low field shifted in comparison with the related resonance observed for trifluoroacetic acid $(\delta 114.8 \mathrm{ppm}$, ${ }^{1} J_{\mathrm{C}-\mathrm{F}}=284.5 \mathrm{~Hz}$ ) (Figure S8). These results confirm the formation of at least two silylester species with the $\mathrm{CF}_{3} \mathrm{CO}_{2} \mathrm{Si}$ moiety but different from $10 \mathrm{~d}$. This behavior could be explained taking into account that complex 8 promoted the rearrangement of $\mathrm{HSiMe}\left(\mathrm{OSiMe}_{3}\right)_{2}$ in absence of coordinating substrates to give mixtures of $\mathrm{HSi}\left(\mathrm{OSiMe}_{3}\right)_{3}, \quad \mathrm{HSiMe}_{2}\left(\mathrm{OSiMe}_{3}\right)$ and other hydrosiloxanes. ${ }^{[14]}$ Indeed, when using $\mathrm{HSiEt}_{3}$ or $\mathrm{HSiMe}_{2} \mathrm{Ph}$ instead of $\mathrm{HSiMe}\left(\mathrm{OSiMe}_{3}\right)_{2}$ under the same reaction conditions the selective 8-catalyzed silylation of $\mathrm{CF}_{3} \mathrm{COOH}$ to give the corresponding silyl-ester $\mathrm{CF}_{3} \mathrm{COOSiEt}_{3} \quad$ (10e) or $\mathrm{CF}_{3} \mathrm{COOSiMe}_{2} \mathrm{Ph}$ (10f) was achieved in $1.5 \mathrm{~h}$ (Table 2). Compounds $10 \mathrm{e}$ and $10 \mathrm{f}$ were characterized by means of ${ }^{1} \mathrm{H}$, ${ }^{29} \mathrm{Si}$ and ${ }^{13} \mathrm{C}\left\{{ }^{1} \mathrm{H}\right\}$ NMR spectroscopy (Figure S9 to S14). It should be noted that the silylesters $10 \mathrm{e}$ and $10 \mathrm{f}$ were previously obtained in low yield from the reaction of the corresponding silane, $\mathrm{HSiEt}_{3}$ or $\mathrm{HSiMe}_{2} \mathrm{Ph}$, with 3 equivalents of $\mathrm{CF}_{3} \mathrm{COOH}$ at $343 \mathrm{~K}$ for $10 \mathrm{~h}^{[23]}$

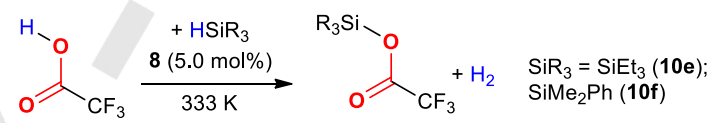

Table 2. Reaction products from the reaction of $\mathrm{CF}_{3} \mathrm{COOH}$ with one equivalent of $\mathrm{HSiR}_{3}$ in presence of catalytic amounts complex $8(5.0 \mathrm{~mol} \%)$ in $\mathrm{C}_{6} \mathrm{D}_{6}$

\begin{tabular}{cccc}
\hline Silane & catalyst & $\mathrm{T}(\mathrm{K})$ & Silyl ester $(\%)^{[\mathrm{a}][\mathrm{b}]}$ \\
\hline $\mathrm{HSiMe}\left(\mathrm{OSiMe}_{3}\right)_{2}$ & $\mathbf{8}$ & 328 & mixture of silylesters \\
$\mathrm{HSiEt}_{3}$ & $\mathbf{8}$ & 328 & $\mathbf{1 0 e}(91.0)$ \\
$\mathrm{HSiMe}_{2} \mathrm{Ph}$ & $\mathbf{8}$ & 328 & $\mathbf{1 0 f}(93.0)$ \\
\hline
\end{tabular}

[a] \% calculated by ${ }^{1} \mathrm{H}$ NMR integration using hexamethylbenzene $(0.07$ $\mathrm{mmol}$ ) as internal standard. [b] Data corresponding to the ${ }^{1} \mathrm{H}$ NMR spectra registered after $1.5 \mathrm{~h}$ of reaction.

A mechanism proposed for the 8-dehydrogenative silylation of the above mentioned carboxylic acids is shown in Scheme 4. It has been proven that $\mathrm{C}_{6} \mathrm{D}_{6}$ solutions of 8 did not react with the carboxylic acids in absence of silane. Therefore, it is reasonable to assume that, analogously to that reported for the 8-catalyzed $\mathrm{CO}_{2}$-hydrosilylation processes, ${ }^{[14]}$ the first step of the reaction could be the formation of species $\mathbf{A}$, which is in equilibrium with B (Scheme 4). ${ }^{[14]}$ This is also supported by the experimentally observed formation of cyclooctane. Intramolecular elimination of molecular hydrogen from $\mathbf{C}$ could afford $\mathbf{D}$. Subsequently, the $\left(n^{2}-\mathrm{Si}-\mathrm{H}\right)$-coordination of a molecule of silane ${ }^{[14]}$ to the free vacancy in $\mathbf{D}$ affords intermediate $\mathbf{E}$ (related to $\mathbf{A}$ ). The carboxylate ligand assisted $\mathrm{Si}-\mathrm{H}$ bond activation leads to the silyl-hydride intermediate $\mathbf{F}$ (related to $\mathbf{B}$ ), which contains a molecule of the corresponding silylester $\mathrm{K}^{1}-\mathrm{O}$-bonded to iridium. Finally, the substitution of the silylester in $\mathbf{F}$ by a molecule of the corresponding carboxylic acid regenerates the active species $\mathbf{C}$. This mechanistic proposal is based on Ir-NSiN intermediates and/or transition states which have been recently reported. ${ }^{[14]}$ 


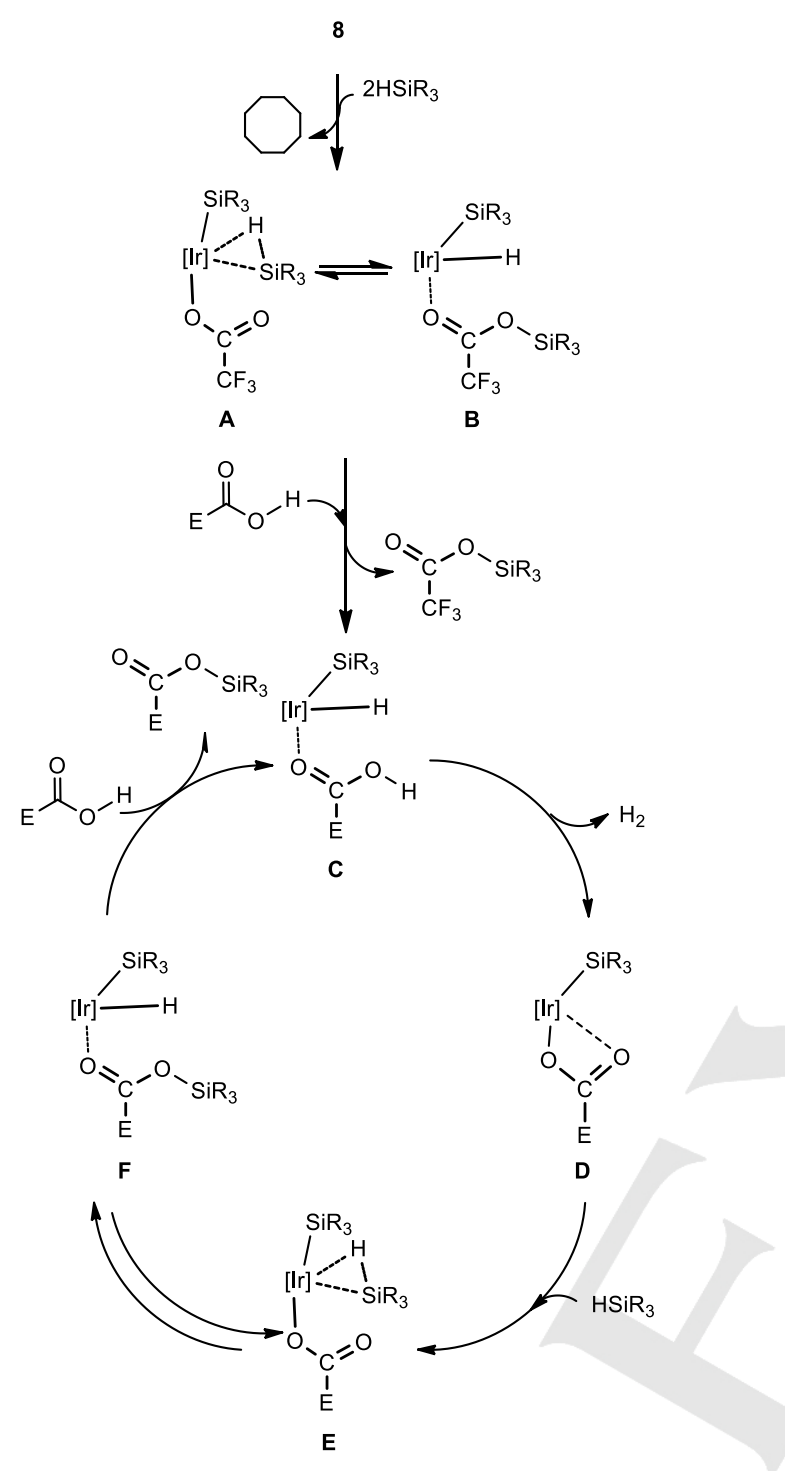

Scheme 4. Mechanism proposal for the 8-catalyzed dehydrogenative silylation of carboxylic acids. [Ir] $=[\operatorname{lr}($ fac-NSiN $)] ; \mathrm{E}=\mathrm{H}, \mathrm{CH}_{3}$ or $\left.\mathrm{Ph}\right)$.

\section{Conclusions}

The potential of $[\operatorname{lr}(\mu-\mathrm{Cl})(\operatorname{cod})]_{2}$ as metallic precursor for the preparation of Ir-NSiN species and the reactivity of the resulting compounds have been successfully studied. The complex $\left.\left[\operatorname{lr}(\mathrm{H})(\mathrm{Cl})(\mathrm{NSiN})\left(\eta^{2}-\mathrm{cod}\right)\right)\right](2)$ reacts with silver triflate to afford the ionic species $\left.\left[\operatorname{Ir}(\mathrm{H})(\mathrm{NSiN})\left(\eta^{4}-\mathrm{cod}\right)\right)\right]\left[\mathrm{CF}_{3} \mathrm{SO}_{3}\right]$ (3). The uncommon $\eta^{2}$-cod coordination mode of the cod ligand to the iridium atom in 2 has been confirmed by X-ray diffraction methods. The reactivity of the Ir-NSiN(olefin) species with $\mathrm{PCy}_{3}$ evidenced that the olefin ligand is easily replaced by the phosphane to give $\left[\operatorname{lr}(\mathrm{H})(\mathrm{X})(\mathrm{NSiN})\left(\mathrm{PCy}_{3}\right)\right]\left(\mathrm{X}=\mathrm{Cl}, \mathrm{CF}_{3} \mathrm{SO}_{3}\right)$ complexes.

On the other hand, the trifluoroacetate derivative $\left[\operatorname{lr}(\mathrm{H})\left(\mathrm{CF}_{3} \mathrm{CO}_{2}\right)(\mathrm{NSiN})(\mathrm{coe})\right](8)$ has proven to be an efficient catalyst for the selective dehydrogenative silylation of $\mathrm{ECOOH}$ $\left(\mathrm{E}=\mathrm{H}, \mathrm{CH}_{3}\right.$ and $\mathrm{Ph}$ ) to give the corresponding silylester. Conversely, when the reaction with $\mathrm{CF}_{3} \mathrm{COOH}$ was studied under the same reaction conditions the expected silylester was obtained as minor product together with a mixture of not identified compounds containing the $\mathrm{CF}_{3} \mathrm{CO}_{2} \mathrm{Si}$ moiety. This behaviour could be due to 8-catalyzed rearrangement of $\mathrm{HSiMe}\left(\mathrm{OSiMe}_{3}\right)_{2}$. Indeed, the reaction of $\mathrm{CF}_{3} \mathrm{COOH}$ with $\mathrm{HSiEt}_{3}$ or $\mathrm{HSiMe}_{2} \mathrm{Ph}$ in presence of catalytic amounts of 8 quantitatively affords the corresponding silylester $\mathrm{CF}_{3} \mathrm{COOSiEt}_{3}$ or $\mathrm{CF}_{3} \mathrm{COOSiMe}_{2} \mathrm{Ph}$, respectively.

\section{Experimental Section}

General Considerations. All reactions and manipulations were carried out under an argon atmosphere using Schlenk-type techniques. Organic solvents were dried by standard procedures and distilled under argon prior to use or obtained oxygen- and water-free from a Solvent Purification System (Innovative Technologies). NMR spectra were obtained on a Bruker AV-300 and AV-400 spectrometer using TMS as the internal reference. All chemical shifts $(\delta)$ are reported in ppm and coupling constants $(J)$ are reported in $\mathrm{Hz}$ to apparent peak multiplications. ${ }^{1} \mathrm{H}-{ }^{1} \mathrm{H}-\mathrm{COSY},{ }^{13} \mathrm{C}-\mathrm{APT},{ }^{1} \mathrm{H} /{ }^{13} \mathrm{C} \mathrm{HSQC},{ }^{1} \mathrm{H} /{ }^{13} \mathrm{C} \mathrm{HMBC}$ and ${ }^{1} \mathrm{H} /{ }^{29} \mathrm{Si} \mathrm{HMBC}$ sequences were used for help in the assignments of the ${ }^{1} \mathrm{H}$ and ${ }^{13} \mathrm{C}$ spectra. Compound 1 and the Ir-NSiN precursors $4,{ }^{[8]} 7^{[8]}$ and $8^{[12]}$ were prepared according to the reported method. $\mathrm{RCO}_{2} \mathrm{H}(\mathrm{R}=\mathrm{H}$, $\mathrm{CH}_{3}, \mathrm{CF}_{3}$ and $\mathrm{Ph}$ ) and $\mathrm{PCy}_{3}$, were purchased from commercial sources and used without further purifications.

Preparation of $\mathrm{IrHCl}\left(\eta^{2}-\mathrm{cod}\right)(\mathrm{NSiN})$ (2). A solution of $[\mathrm{IrCl}(\mathrm{cod})]_{2}(0.202$ $\mathrm{g}, 0.30 \mathrm{mmol})$ in $7 \mathrm{~mL}$ of dichloromethane was treated with 1.0 equiv of bis-(2-(oxy)pyridine)methylsilane $1(0.140 \mathrm{~g}, 0.60 \mathrm{mmol})$ and stirred at room temperature for $3 \mathrm{~h}$. Then, the solvent was removed in vacuum. The addition of hexane $(3 \mathrm{~mL})$ led to a white solid, which was separated by decantation, washed with further portions of hexane $(3 \times 3 \mathrm{~mL})$ and dried in vacuum. Yield: $0.297 \mathrm{~g}(87 \%)$. Anal. calcd. for $\mathrm{C}_{19} \mathrm{H}_{24} \mathrm{~N}_{2} \mathrm{IrClO} \mathrm{CO}_{2} \mathrm{Si}$ (568.165): C, 40.17; H, 4.26; N, 4.93. Found: C, 39.45; H, 4.25; N, 5.85. Mass spectrometry (ESI): $\mathrm{m} / \mathrm{z} 533.1,[\mathrm{M}-\mathrm{Cl}]^{+}(100 \%)$.

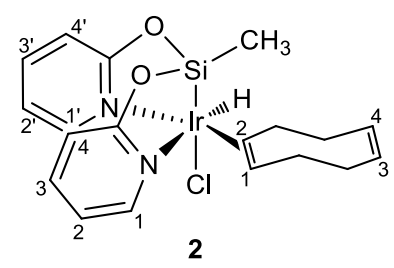

${ }^{1} \mathrm{H}$ NMR plus COSY and NOESY $\left(400.13 \mathrm{MHz}, \mathrm{CD}_{2} \mathrm{Cl}_{2}, 298 \mathrm{~K}\right): \delta 9.53$ (ddd, $\left.J_{\mathrm{H}-\mathrm{H}}=6.1,1.9,0.6,1 \mathrm{H}, \mathrm{H}^{-1}{ }_{\mathrm{py}}\right), 9.25-9.22\left(\mathrm{~m}, 1 \mathrm{H}, \mathrm{H}_{\mathrm{py}}^{1}\right), 7.71$ (ddd, $\left.J_{\mathrm{H}-\mathrm{H}}=8.3,7.2,2.0,1 \mathrm{H}, \mathrm{H}_{\text {py }}^{3}\right), 7.65\left(\mathrm{ddd}, J_{\mathrm{H}-\mathrm{H}}=8.4,7.2,1.9,1 \mathrm{H}, \mathrm{H}^{\prime 3}{ }_{\text {py }}\right.$ ), 7.01-6.95 (m, 2H, $\left.\mathrm{H}_{p y}\left(\mathrm{H}_{4}+\mathrm{H}_{2}\right)\right), 6.93$ (ddd, $\mathrm{J}_{\mathrm{H}-\mathrm{H}}=8.3,1.3,0.6,1 \mathrm{H}, \mathrm{H}^{\prime 4}{ }_{\mathrm{py}}$ ), $6.79\left(\mathrm{ddd}, \mathrm{J}_{\mathrm{H}-\mathrm{H}}=7.3,6.1,1.4,1 \mathrm{H}, \mathrm{H}_{\mathrm{py}}^{2}\right), 5.67-5.51\left(\mathrm{~m}, 2 \mathrm{H},=\mathrm{CH}^{3.4}{ }_{\operatorname{cod}}\right)$, 4.61-4.54 (m, $\left.1 \mathrm{H},=\mathrm{CH}^{2}{ }_{\text {cod }}\right), 3.83-3.75\left(\mathrm{~m}, 1 \mathrm{H},=\mathrm{CH}^{1}{ }_{\text {cod }}\right), 2.60-1.32(\mathrm{~m}, 8 \mathrm{H}$, $\left.-\mathrm{CH}_{2-\mathrm{cod}}\right), 0.69\left(\mathrm{~s}, \mathrm{SiCH}_{3}, 3 \mathrm{H}\right),-15.35(\mathrm{~s}, 1 \mathrm{H}, \mathrm{Ir}-\mathrm{H}) .{ }^{13} \mathrm{C}-\mathrm{APT}$ NMR plus $\mathrm{HMBC}$ and $\mathrm{HSQC}\left(100.4 \mathrm{MHz}, \mathrm{CD}_{2} \mathrm{Cl}_{2}, 298 \mathrm{~K}\right): \delta 167.6$ and 165.8 (both

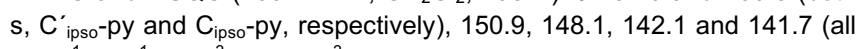
$\mathrm{s}, \mathrm{C}_{\mathrm{py}}^{-1}, \mathrm{C}_{\mathrm{py}}^{1}, \mathrm{C}_{\mathrm{py}}^{.3}$ and $\mathrm{C}_{\mathrm{py}}^{3}$, respectively), 130.2 and 130.1 (both $\mathrm{s}$, $=\mathrm{CH}^{3,4}{ }_{\text {cod }}$ ), 118.3, 117.4, 112.7 and 112.0 (all s, $\mathrm{C}_{\mathrm{py}}^{2}, \mathrm{C}_{\mathrm{py}}{ }^{2}, \mathrm{C}_{\mathrm{py}}^{4}, \mathrm{C}_{\mathrm{py}} \mathrm{s}^{4}$ 
respectively), 68.7 and 65.9 (both s, $=\mathrm{CH}^{2}$ cod and $=\mathrm{CH}^{1}$ cod, respectively), 35.0, 32.7, 31.4 and 30.8 (all s, $-\mathrm{CH}_{2}-\mathrm{cod}$ ), $\left.-1.0\left(\mathrm{~s}, \mathrm{SiCH}_{3}\right) .{ }^{29} \mathrm{Si}^{1}{ }^{1} \mathrm{H}\right\} \mathrm{NMR}$ $\left(59.6 \mathrm{MHz}, \mathrm{CD}_{2} \mathrm{Cl}_{2}, 298 \mathrm{~K}\right): \delta 31.3\left(\mathrm{~s}, \mathrm{SiCH}_{3}\right)$.

Preparation of $\left[\mathrm{IrH}\left(\eta^{4}-\mathrm{Cod}\right)\left(\mathrm{NSiN}^{2}\right)\right]\left(\mathrm{CF}_{3} \mathrm{SO}_{3}\right)(3)$. A solution of $2(0.179 \mathrm{~g}$ $0.32 \mathrm{mmol}$ ) in $12 \mathrm{~mL}$ of THF was treated with 1.0 equiv of silver trifluoromethanesulfonate $(0.081 \mathrm{~g}, 0.32 \mathrm{mmol})$ in the absence of light. After stirring the mixture for $1.5 \mathrm{~h}$ at room temperature, the suspension was filtered through Celite and the filtrate was evaporated to dryness. The addition of hexane $(3 \mathrm{~mL})$ caused the precipitation of a light orange solid, which was separated by decantation, washed with further portions of hexane $(3 \times 3 \mathrm{~mL})$, and dried in vacuum. Yield: $0.176 \mathrm{~g}(82 \%)$. Anal calcd. for $\mathrm{C}_{20} \mathrm{H}_{24} \mathrm{~N}_{2} \mathrm{SF}_{3}$ IrO $\mathrm{O}_{5} \mathrm{Si}$ (681.778): C, 35.23; $\mathrm{H}, 3.55 ; \mathrm{N}, 4.11 ; \mathrm{S}$, 4.70. Found: C, $34.78 ; \mathrm{H}, 3.58 ; \mathrm{N}, 3.99, \mathrm{~S}, 4.48$. Mass spectrometry (ESI): $\mathrm{m} / \mathrm{z}$ 533.1, [M] $]^{+}(100 \%)$.

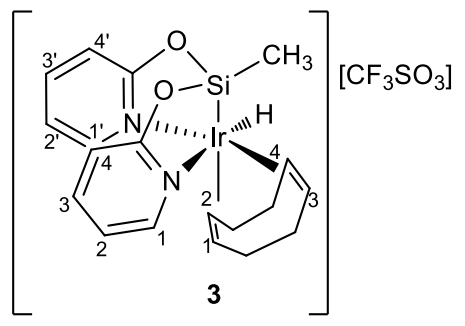

${ }^{1} \mathrm{H}$ NMR plus COSY and NOESY $\left(400.13 \mathrm{MHz}, \mathrm{CD}_{2} \mathrm{Cl}_{2}, 298 \mathrm{~K}\right): 8.84$ (ddd, $\left.J_{\mathrm{H}-\mathrm{H}}=6.0,1.6,0.8,1 \mathrm{H}, \mathrm{H}_{\mathrm{py}}^{1}\right), 7.96$ (ddd, $J_{\mathrm{H}-\mathrm{H}}=6.1,1.3,0.4,1 \mathrm{H}$, $\left.\mathrm{H}^{-1}{ }_{\mathrm{py}}\right), 7.90$ (ddd, $\left.J_{\mathrm{H}-\mathrm{H}}=8.4,7.3,1.8,1 \mathrm{H}, \mathrm{H}_{\mathrm{py}}^{3}\right), 7.80$ (ddd, $J_{\mathrm{H}-\mathrm{H}}=8.5,7.3$, $\left.1.8,1 \mathrm{H}, \mathrm{H}^{\prime 3}{ }_{\mathrm{py}}\right), 7.19$ (ddd, $\left.\mathrm{J}_{\mathrm{H}-\mathrm{H}}=7.3,6.0,1.3,1 \mathrm{H}, \mathrm{H}_{\mathrm{py}}{ }^{2}\right), 7.10-7.08(\mathrm{~m}, 1 \mathrm{H}$, $\left.\mathrm{H}_{\mathrm{py}}^{4}\right), 7.08-7.06\left(\mathrm{~m}, 1 \mathrm{H}, \mathrm{H}_{\mathrm{py}}^{4}\right), 7.00\left(\mathrm{ddd}, \mathrm{J}_{\mathrm{H}-\mathrm{H}}=7.4,6.1,1.4,1 \mathrm{H}, \mathrm{H}^{\prime 2}{ }_{\mathrm{py}}\right)$, 5.97-5.91 $\left(\mathrm{m}, 1 \mathrm{H},=\mathrm{CH}^{2}{ }_{\text {cod }}\right), 4.71-4.64\left(\mathrm{~m}, 1 \mathrm{H},=\mathrm{CH}^{4}{ }_{\text {cod }}\right), 4.54-4.62(\mathrm{~m}, 1 \mathrm{H}$ $\left.=\mathrm{CH}^{1}{ }_{\text {cod }}\right), 3.74-3.69\left(\mathrm{~m}, 1 \mathrm{H},=\mathrm{CH}^{3}{ }_{\text {cod }}\right), 3.00-1.84\left(\mathrm{~m}, 8 \mathrm{H},-\mathrm{CH}_{2-\mathrm{cod}}\right), 0.79(\mathrm{~s}$ $\left.\mathrm{SiCH}_{3}, 3 \mathrm{H}\right),-15.47$ (s, $\left.1 \mathrm{H}, \mathrm{Ir}-\mathrm{H}\right) .{ }^{13} \mathrm{C}-\mathrm{APT}$ NMR plus HMBC and HSQC $\left(100.4 \mathrm{MHz}, \mathrm{CD}_{2} \mathrm{Cl}_{2}, 298 \mathrm{~K}\right.$ ): $\delta 167.3$ and 166.1 (both s, $\mathrm{C}^{\prime}$ ipso-py and

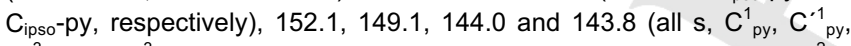
$\mathrm{C}^{\prime 3}$ py and $\mathrm{C}^{3}{ }_{\mathrm{py}}$, respectively), 121.1, 120.3, 114.0 and 113.7 (all $\mathrm{S}, \mathrm{C}^{2}{ }_{\mathrm{py}}$, $\mathrm{C}^{\prime 2}{ }_{\mathrm{py}}, \mathrm{C}_{\mathrm{py}}^{4}, \mathrm{C}_{\mathrm{py}}{ }^{4}$, respectively), 112.5, 105.8, 69.2 and 69.0 (all $\mathrm{s}$, $=\mathrm{CH}_{\text {cod, }}{ }^{4}=\mathrm{CH}_{\text {cod }}^{1},=\mathrm{CH}_{\text {cod }}^{3}=\mathrm{CH}^{4}$ cod, respectively), 35.9, 35.1, 31.5 and 22.4 (all s, $-\mathrm{CH}_{2}$-cod), -1.5 (s, $\left.\mathrm{SiCH}_{3}\right) .{ }^{29} \mathrm{Si}\left\{{ }^{1} \mathrm{H}\right\}$ NMR $\left(59.6 \mathrm{MHz}, \mathrm{CD}_{2} \mathrm{Cl}_{2}\right.$, $298 \mathrm{~K}): \delta 51.5\left(\mathrm{~s}, \mathrm{SiCH}_{3}\right) .{ }^{19} \mathrm{~F} \mathrm{NMR}\left(282.4 \mathrm{MHz}, \mathrm{CD}_{2} \mathrm{Cl}_{2}, 298 \mathrm{~K}\right): \delta-78.8$ $\left(\mathrm{s}, \mathrm{CF}_{3}\right)$.

Preparation of $\left[\operatorname{lr}(\mathbf{H})(\mathbf{C l})\left(\mathrm{NSiN}_{(}\right)\left(\mathrm{PC}_{\mathbf{3}}\right)\right]$ (5). Complex $2(0.200 \mathrm{~g}, 0.35$ $\mathrm{mmol}$ ) and $\mathrm{PCy}_{3}(0.980 \mathrm{~g}, 0.35 \mathrm{mmol})$ were mixed inside the glovebox and then $8.0 \mathrm{~mL}$ of toluene were added to give a yellow solution, which was stirred at room temperature during $24 \mathrm{~h}$. The solvent was removed in vacuum and the resulting residue was washed with hexane $(2 \times 3 \mathrm{~mL}$. $)$ and dried in vacuum to obtain a white powder. Yield: $0.210 \mathrm{~g}(80 \%)$. Anal. calcd. for $\mathrm{C}_{29} \mathrm{H}_{45} \mathrm{CllrN}_{2} \mathrm{O}_{2} \mathrm{PSi}$ : C, 47.04; $\mathrm{H}, 6.13 ; \mathrm{N}, 3.78$. Found: $\mathrm{C}$ 46.78; $\mathrm{H}, 6.20 ; \mathrm{N}, 3.87 .{ }^{1} \mathrm{H}$ NMR plus HSQC $\left(300 \mathrm{MHz}, 298 \mathrm{~K}, \mathrm{CDCl}_{3}\right): \delta$ $9.64(\mathrm{~m}, 1 \mathrm{H}, \mathrm{py}), 9.40(\mathrm{~m}, 1 \mathrm{H}, \mathrm{py}), 7.54\left(\mathrm{t}, \mathrm{J}_{\mathrm{H}-\mathrm{H}}=7.6 \mathrm{~Hz}, 1 \mathrm{H}, \mathrm{py}\right), 7.48(\mathrm{t}$, $\left.\mathrm{J}_{\mathrm{H}-\mathrm{H}}=7.6 \mathrm{~Hz}, 1 \mathrm{H}, \mathrm{py}\right), 6.91-6.68(\mathrm{~m}, 4 \mathrm{H}, \mathrm{py}), 2.01-1.07(\mathrm{~m}, 33 \mathrm{H}, \mathrm{Cy})$, $0.81(\mathrm{~s}, 3 \mathrm{H}, \mathrm{Me}),-20.47\left(\mathrm{~d}, \mathrm{~J}_{\mathrm{H}-\mathrm{P}}=23 \mathrm{~Hz}, \mathrm{Ir}-\mathrm{H}\right) .{ }^{31} \mathrm{P}\left\{{ }^{1} \mathrm{H}\right\} \mathrm{NMR}(121 \mathrm{MHz}$, $\left.298 \mathrm{~K}, \mathrm{C}_{6} \mathrm{D}_{6}\right) \delta 15.0\left(\mathrm{~s}, \mathrm{PCy}_{3}\right) \cdot{ }^{13} \mathrm{C}-\mathrm{APT}$ plus HSQC and HMBC NMR $(75$ $\mathrm{MHz}, 298 \mathrm{~K}, \mathrm{CDCl}_{3}$ ): $\delta 166.1,166.0$ (s, C $\mathrm{C}_{\text {ipso-py), }}$ 148.6, 148.1, 140.0, 139.8, 116.6, 116.5, 111.8 and 111.2, (s, CH-py), 36.8 and 35.0 (br s, $\left.\mathrm{CH}-\mathrm{PCy}_{3}\right), 29.3,27.6,26.7\left(\mathrm{CH}_{2}\right.$-Cy). ${ }^{29} \mathrm{Si}$ NMR (DEPT 45, $60 \mathrm{MHz}, 298$ $\left.\mathrm{K}, \mathrm{C}_{6} \mathrm{D}_{6}\right): \delta 41.3\left(\mathrm{~d}, \mathrm{~J}_{\mathrm{Si}-\mathrm{P}}=14.9 \mathrm{~Hz}, \mathrm{SiMe}\right) . \mathrm{ESI}^{+}: 705.2\left[\mathrm{M}^{+}-\mathrm{Cl}, 100 \%\right]$.
Preparation of $\left[\mathrm{Ir}(\mathrm{H})\left(\mathrm{CF}_{3} \mathrm{SO}_{3}\right)(\mathrm{NSiN})\left(\mathrm{PCy}_{3}\right)\right]$ (6). A solution of $5(0.250 \mathrm{~g}$, $0.32 \mathrm{mmol}$ ) in $12 \mathrm{~mL}$ of THF was treated with 1.0 equiv of silver trifluoromethanesulfonate $(0.081 \mathrm{~g}, 0.32 \mathrm{mmol})$ in the absence of light. After stirring the mixture for $1.5 \mathrm{~h}$ at room temperature, the suspension was filtered through Celite and the filtrate was evaporated to dryness. The addition of hexane $(3 \mathrm{~mL})$ caused the precipitation of a light orange solid, which was separated by decantation, washed with further portions of hexane $(3 \times 3 \mathrm{~mL})$, and dried in vacuum. Yield: $0.268 \mathrm{~g}(84 \%) .{ }^{1} \mathrm{H}$ NMR (300 MHz, $\left.\mathrm{CD}_{2} \mathrm{Cl}_{2}\right): \delta 8.62(\mathrm{~m}, 2 \mathrm{H}, \mathrm{py}), 7.63(\mathrm{~m}, 2 \mathrm{H}, \mathrm{py}), 6.97(\mathrm{~m}$, $1 \mathrm{H}, \mathrm{py}), 6.89(\mathrm{~m}, 3 \mathrm{H}, \mathrm{py}), 2.24$ (brs, 3H, P-CH), $1.70(\mathrm{~m}, 15 \mathrm{H}, \mathrm{Cy}), 1.25$ (m, 15H, Cy), 0.86 (s, 3H, SiMe), -19.17 (d, JP-H $=22.5 \mathrm{~Hz}, 1 \mathrm{H}, \mathrm{Ir}-\mathrm{H}) .{ }^{13} \mathrm{C}-$ APT NMR plus HSQC and HMBC $\left(75 \mathrm{MHz}, \mathrm{CD}_{2} \mathrm{Cl}_{2}\right)$ : $\delta 165.2$ (br, $\mathrm{C}_{\text {ipso, }}$ 2C, py), 147.4 (s, 2C, CH-py), 141.0, 140.9 and 118.1 (s, CH-py), 117.6 (d, ${ }^{3} \mathrm{JP}_{\mathrm{P}-\mathrm{C}}=2.5 \mathrm{~Hz}, \mathrm{CH}-\mathrm{py}$ ), 112.8 and 112.3 (s, CH-py), 37.0 (d, ${ }^{1} \mathrm{~J}=31.4$ $\mathrm{Hz}, \mathrm{P}-\mathrm{C}), 30.1$ (d, $\left.{ }^{4} \mathrm{~J}=2.5 \mathrm{~Hz}, \mathrm{Cy}\right), 29.3$ (br s, Cy), 27.9 (d, ${ }^{3} \mathrm{~J}=11.0 \mathrm{~Hz}$, Cy), 27.7 (d, ${ }^{3} \mathrm{~J}=10.8 \mathrm{~Hz}, \mathrm{Cy}$ ), 27.0 (s, Cy), 0.20 (s, SiMe). ${ }^{1} \mathrm{H}^{29} \mathrm{Si}^{-}$ $\operatorname{HMBC} \operatorname{NMR}\left(\mathrm{C}_{6} \mathrm{D}_{6}\right): \delta 15.3(\mathrm{SiMe})$.

General procedure for the NMR scale reactions of equimolar mixtures of $\mathrm{HSiMe}\left(\mathrm{OSiMe}_{3}\right)_{2}$ with carboxylic acids. A NMR tube was charged with the precursor catalyst 7 or $8\left(3.510^{-3} \mathrm{mmol}\right)$ and $\mathrm{C}_{6} \mathrm{D}_{6}(0.5$ $\mathrm{mL})$. After which, $\mathrm{HSiMe}\left(\mathrm{OSiMe}_{3}\right)_{2}(22 \mu \mathrm{L}, 0.07 \mathrm{mmol})$ and the corresponding carboxylic acid $(0.07 \mathrm{mmol})$ and hexamethylbenzene as internal standard $(0.07 \mathrm{mmol})$ were added to the homogeneous solution and the resulting mixtures were heated at $333 \mathrm{~K}$ and monitored by ${ }^{1} \mathrm{H}$ NMR spectroscopy.

Selected data for 10b. ${ }^{1} \mathrm{H}$ NMR $\left(300 \mathrm{MHz}, 298 \mathrm{~K}, \mathrm{C}_{6} \mathrm{D}_{6}\right): \delta 1.70(\mathrm{~s}, 3 \mathrm{H}$, $\left.\mathrm{CH}_{3}\right), 0.37$ (s, 3H, SiMe), 0.20 (s, 18H, OSiMe 3 ). ${ }^{13} \mathrm{C}-\mathrm{APT}$ NMR plus $\mathrm{HSQC}$ and $\mathrm{HMBC}\left(75 \mathrm{MHz}, \mathrm{C}_{6} \mathrm{D}_{6}\right): \delta 169.7\left(\mathrm{~s}, \mathrm{CO}_{2}\right), 22.3\left(\mathrm{~s}, \mathrm{CH}_{3}\right), 1.6(\mathrm{~s}$, $\left.\mathrm{OSiMe}_{3}\right),-2.6$ (s, SiMe). ${ }^{29} \mathrm{Si}\left\{{ }^{1} \mathrm{H}\right\}$ plus ${ }^{1} \mathrm{H}^{29}{ }^{29} \mathrm{Si}-\mathrm{HMBC}$ NMR $(60 \mathrm{MHz}, 298$ $\left.\mathrm{K}, \mathrm{C}_{6} \mathrm{D}_{6}\right): \delta 10.0\left(\mathrm{~s}, \mathrm{OSiMe}_{3}\right),-58.2(\mathrm{~s}, \mathrm{SiMe})$.

Selected data for 10c. ${ }^{1} \mathrm{H}$ NMR $\left(300 \mathrm{MHz}, 298 \mathrm{~K}, \mathrm{C}_{6} \mathrm{D}_{6}\right): \delta 8.20(\mathrm{~m}, 2 \mathrm{H}$, $\mathrm{Ph}), 7.06(\mathrm{~m}, 3 \mathrm{H}, \mathrm{Ph}), 0.48(\mathrm{~s}, 3 \mathrm{H}, \mathrm{SiMe}), 0.23\left(\mathrm{~s}, 18 \mathrm{H}, \mathrm{OSiMe}_{3}\right) .{ }^{13} \mathrm{C}-$ APT NMR plus HSQC and HMBC $\left(75 \mathrm{MHz}, \mathrm{C}_{6} \mathrm{D}_{6}\right)$ : $\delta 165.6\left(\mathrm{~s}, \mathrm{CO}_{2}\right)$, 133.1 (s, CH, Ph), 131.7 (s, $\left.\mathrm{C}_{\text {ipso }}, \mathrm{Ph}\right), 130.5$ (s, CH, Ph) 128.5 (s, CH, $\mathrm{Ph}), 1.7$ (s, OSiMe 3 ), -2.5 (s, SiMe). $\left.{ }^{29} \mathrm{Si}^{1}{ }^{1} \mathrm{H}\right\} \mathrm{NMR}(60 \mathrm{MHz}, 298 \mathrm{~K}$, $\left.\mathrm{C}_{6} \mathrm{D}_{6}\right): \delta 10.3$ (s, OSiMe $\left.)_{3}\right),-57.0$ (s, SiMe).

Selected data for 10e. ${ }^{1} \mathrm{H}$ NMR $\left(400 \mathrm{MHz}, 298 \mathrm{~K}, \mathrm{C}_{6} \mathrm{D}_{6}\right): \delta 0.56$ (q, $6 \mathrm{H}$, $\left.{ }^{3} J_{\mathrm{H}-\mathrm{H}}=7.7, \mathrm{CH}_{2}\right), 0.78\left(\mathrm{t}, 9 \mathrm{H},{ }^{3} \mathrm{~J}_{\mathrm{H}-\mathrm{H}}=7.7, \mathrm{CH}_{3}\right) \cdot{ }^{13} \mathrm{C}\left\{{ }^{1} \mathrm{H}\right\}$ NMR plus HSQC $\left(100 \mathrm{MHz}, \mathrm{C}_{6} \mathrm{D}_{6}\right): \delta 156.5\left(\mathrm{q},{ }^{2} \mathrm{~J}_{\mathrm{C}-\mathrm{F}}=42.0, \mathrm{CO}_{2}\right), 115.2\left(\mathrm{q},{ }^{1} \mathrm{~J}_{\mathrm{C}-\mathrm{F}}=286.5\right.$, $\left.\mathrm{CF}_{3}\right), 5.8\left(\mathrm{~s}, \mathrm{CH}_{3}\right), 4.0\left(\mathrm{~s}, \mathrm{CH}_{2}\right) .{ }^{29} \mathrm{Si}\left\{{ }^{1} \mathrm{H}\right\}$ NMR $\left(99.0 \mathrm{MHz}, 298 \mathrm{~K}, \mathrm{C}_{6} \mathrm{D}_{6}\right): \delta$ 34.5 (s). ${ }^{19} \mathrm{~F}\left\{{ }^{1} \mathrm{H}\right\}$ NMR $\left(282 \mathrm{MHz}, 298 \mathrm{~K}, \mathrm{C}_{6} \mathrm{D}_{6}\right): \delta-75.8$ (s).

Selected data for 10f. ${ }^{1} \mathrm{H}$ NMR $\left(400 \mathrm{MHz}, 298 \mathrm{~K}, \mathrm{C}_{6} \mathrm{D}_{6}\right): \delta 7.42(\mathrm{~m}, 2 \mathrm{H}$, $\mathrm{Ph}), 7.12(\mathrm{~m}, 3 \mathrm{H}, \mathrm{Ph}), 0.30\left(\mathrm{~s}, 6 \mathrm{H}, \mathrm{SiMe}_{2}\right) \cdot{ }^{13} \mathrm{C}\left\{{ }^{1} \mathrm{H}\right\}$ NMR plus HSQC $(100$ $\left.\mathrm{MHz}, \mathrm{C}_{6} \mathrm{D}_{6}\right): \delta 156.7\left(\mathrm{q},{ }^{2} \mathrm{~J}_{\mathrm{C}-\mathrm{F}}=42.0, \mathrm{CO}_{2}\right), 114.9\left(\mathrm{q},{ }^{1} \mathrm{~J}_{\mathrm{C}-\mathrm{F}}=282.2, \mathrm{CF}_{3}\right)$, 128.5, 131.3 and 133.4 (s, CH, Ph), 133.1 (s, $\left.\mathrm{C}_{\text {ipso }}, \mathrm{Ph}\right),-2.5$ (s, $\mathrm{SiMe}_{2}$ ). ${ }^{29} \mathrm{Si}\left\{{ }^{1} \mathrm{H}\right\}$ NMR (99.0 MHz, $\left.298 \mathrm{~K}, \mathrm{C}_{6} \mathrm{D}_{6}\right): \delta 20.5$ (s). ${ }^{19} \mathrm{~F}\left\{{ }^{1} \mathrm{H}\right\}$ NMR $(282$ $\left.\mathrm{MHz}, 298 \mathrm{~K}, \mathrm{C}_{6} \mathrm{D}_{6}\right):$ ס -75.9(s).

General procedure for the measurement of $\mathrm{H}_{2}$ evolution from the 1catalyzed reactions of carboxylic acids with $\mathrm{HSiMe}\left(\mathrm{OSiMe}_{3}\right)_{2}$. The reactions were carried out in a Man on the Moon X102 kit ${ }^{8}$ micro-reactor (www.manonthemoontech.com), with a total volume of $19.0 \mathrm{~mL}$, placed in a silicone bath at $333 \mathrm{~K}$. In a typical procedure $1.0 \mathrm{mmol}$ of $\mathrm{HSiMe}\left(\mathrm{OSiMe}_{3}\right)_{2}(281 \mu \mathrm{L}, 1.01 \mathrm{mmol})$ was added to a solution of the catalyst $8(0.01 \mathrm{mmol}, 6.50 \mathrm{mg})$ in $1 \mathrm{~mL}$ of dry-toluene. The reactor was closed and the pressure measurement started. Once the pressure was stabilized, the corresponding $\mathrm{ECOOH}\left(\mathrm{E}=\mathrm{H}, 37.7 \mu \mathrm{L} ; \mathrm{CH}_{3}, 57.2 \mu \mathrm{L} ; 1.0\right.$ mmol) was added with a syringe. In the case of $\mathrm{PhCOOH}, 1.0 \mathrm{mmol}$ of 
$\mathrm{HSiMe}\left(\mathrm{OSiMe}_{3}\right)_{2}(281 \mu \mathrm{L}, 1.01 \mathrm{mmol})$ was added to a solution of the catalyst $8(6.50 \mathrm{mg}, 0.01 \mathrm{mmol})$ and $\mathrm{PhCOOH}(122 \mathrm{mg}, 1.0 \mathrm{mmol})$ in 1 $\mathrm{mL}$ of dry-toluene. Hydrogen evolution was measured till inner pressure in the micro-reactor remained constant. The difference in pressure was used to calculate the amount of $\mathrm{H}_{2}$ produced during the reaction using the Ideal Gas Law, $P \cdot V=n \cdot R \cdot T$.

Crystal Structure Determination of Complexes 2 and 5. Single crystal $\mathrm{X}$-ray diffraction data were collected at $100(2) \mathrm{K}$ with graphitemonochromated MoKa radiation $(\lambda=0.71073 \AA)$ using narrow $\omega$ rotations $\left(0.3^{\circ}\right)$ on a Bruker APEX DUO (compound 2) or a Bruker SMART APEX diffractometer (compound 5). SAINT+ ${ }^{[24]}$ and SADABS ${ }^{[25]}$ programs, integrated in APEX2 package, were used to integrate and correct the absorption effect of the intensities. The structures were solved by direct methods with SHELXS-2013 ${ }^{[26]}$ and refined by full-matrix leastsquares refinement in $F^{2}$ with SHELXL-2014 ${ }^{[27]}$ included in Wingx package ${ }^{[28]}$ Hydride ligand has been included in the model in observed position and freely refined (compound 2 ) or refined with a restraint in Ir-H bond length (compound $\mathbf{5}$ ).

Crystal data for 2. $\mathrm{C}_{29} \mathrm{H}_{24} \mathrm{CllrN}_{2} \mathrm{O}_{2} \mathrm{Si} M=568.14$; yellow prism, $0.070 \times$ $0.082 \times 0.082 \mathrm{~mm}^{3}$; monoclinic $P 2{ }_{1} / c ; a=9.8151(7), b=12.3333(8), c=$ $16.2337(11) \AA, \beta=90.1270(10)^{\circ} ; V=1965.1(2) \AA^{3} ; Z=4 ; \rho_{\text {calc }}=1.920 \mathrm{~g}$ $\mathrm{cm}^{-3} ; \mu=7.007 \mathrm{~cm}^{-1} ; \mathrm{min}$. and max. transmission factors 0.522 and $0.672 ; 2 \theta_{\max }=59.056^{\circ} ; 30016$ reflections collected; 5214 unique reflections $\left[R_{\text {int }}=0.0441\right]$; number of data/restraints/parameters: 5214/0/256; final GOF 1.046; $R_{1}=0.0320$ [4438 reflections, $I>2 \sigma(l)$ ] $w R_{2}=0.0837$ for all data; largest difference peak: $7.05 \mathrm{e} \AA^{-3}$. At the end of the refinement five residual density peaks bigger than 1 e $\AA^{-3}$ have been found. They are close to iridium atom and reveal bonding effects between the metal and the ligands.

Crystal data for 5. $\mathrm{C}_{29} \mathrm{H}_{45} \mathrm{CllrN}_{2} \mathrm{O}_{2} \mathrm{PSi} M=740.38$; colorless prism, $0.060 \times 0.160 \times 0.175 \mathrm{~mm}^{3} ;$ monoclinic $P 21 / c ; a=11.7418(8), b=$ 12.1443(8), $c=21.6800(14) \AA, \beta=104.6250(10)^{\circ} ; V=2991.3(3) \AA^{3} ; Z=$ 4; $\rho_{\text {calc }}=1.644 \mathrm{~g} \mathrm{~cm}^{-3} ; \mu=4.675 \mathrm{~cm}^{-1}$; min. and max. transmission factors 0.498 and $0.640 ; 2 \theta_{\max }=56.214^{\circ} ; 34218$ reflections collected; 7094 unique reflections $\left[R_{\text {int }}=0.0552\right]$; number of data/restraints/parameters: $7094 / 3 / 394$; final GOF $0.982 ; R_{1}=0.0345$ [5637 reflections, $I>2 \sigma(I)], w R_{2}=0.0844$ for all data; largest difference peak: 3.926 e $\AA^{-3}$. At the end of the refinement five residual density peaks bigger than 1 e $\AA^{-3}$ have been found. They are close to iridium atom and have no chemical sense.

CCDC 1574097-1574098 contain the supplementary crystallographic data for this paper. These data can be obtained free of charge from the Cambridge Crystallographic Data Centre via http://www.ccdc.cam.ac.uk/data request/cif.

\section{Acknowledgements}

Financial support from MINECO/FEDER projects: CTQ201342532-P and CTQ2015-67366-P and DGA/FSE group E07) is gratefully acknowledged. Dr. P. García-Orduña acknowledges CSIC, European Social Fund and Ministerio de Economía y Competitividad of Spain for a PTA contract. Authors would like to acknowledge the use of Servicio General de Apoyo a la Investigación-SAI, Universidad de Zaragoza. The support of KFUPM is also appreciated.
Keywords: Carboxylic acids reduction • Silylation • Ir-NSiN • Homogeneous catalysis $\cdot$ Hydrogen generation

[1] For recent reviews see: a) M. C. Lipke, A. L. Liberman-Martin, T. D. Tilley, Angew. Chem. Int. Ed. 2017, 56, 2260-2294; b) D. S. Morris, C. Weetman, J. T. C. Wennmacher, M. Cokoja, M. Drees, F. E. Kühn, J. B. Love, Cat. Sci. Technol. 2017, 7, 2838-2845; c) M. Oestreich, Angew. Chem. Int. Ed. 2016, 55, 494-499; d) A. K. Roy, Adv. Organomet. Chem. 2008, 55, 1-59; e) B. Marciniec, K. H. Maciejewski, C. Pietraszuk, P. Pawluć in Hydrosilylation: A Comprehensive Review on Recent Advances, (Ed.: B. Marciniec), Springer, London, 2008; f) B. Marciniec, C. Pietraszuk, Top. Organomet. Chem. 2004, 11, 197-248; g) I. Ojima, in The Hydrosilylation Reaction: The chemistry of Organosilicon Compounds, (Ed.: S. Patai, Z. Rappoport), Wiley-VCH, New York, 1989.

[2] For recent reviews on selective carboxylic acids reduction see: a) D. S Mérel, M. L. T. Do, S. Gaillard, P. Dupau, J.-L. Renaud, Coord. Chem. Rev. 2015, 288, 50-68; b) D. Addis, S. Das, K. Junge, M. Beller, Angew. Chem. Int. Ed. 2011, 50, 6004-6011.

[3] For a review see: F. J. Fernández-Alvarez, A. M. Aitani, L. A. Oro, Cat Sci. Technol. 2014, 4, 611-624.

[4] a) C. Chauvier, T. Godou, T. Cantat, Chem. Commun. 2017, DOI: 10.1039/C7CC05212J; b) S. Vijjamarri, V. K. Chidara, J. Rousova, G. D. Du, Catal. Sci. Techol. 2016, 6, 3886-3892; c) E. Feghali, O. Jacquet, P. Thuéry, T. Cantat, Catal. Sci. Techol. 2014, 4, 2230-2234; d) Y. Ojima, K. Yamaguchi, N. Mizuno, Adv. Synth. Catal. 2009, 351, 1405-1411; e) G. B. Liu, H. Y. Zhao, T. Thiemann, Adv. Synth. Catal. 2007, 349, $807-$ 811 ; f) M. Chauhan, B. P. S. Chauhan, P. Boudjouk, Org. Lett. 2000, 2 , 1027-1029.

[5] a) J. A. Fernández-Salas, S. Manzini, S. P. Nolan, Adv. Synth. Catal. 2014, 356, 308-312; b) K. Miyamoto, Y. Motoyama, H. Nagashima Chem. Lett. 2012, 41, 229-231; c) K. Matsubara, T. lura, T. Maki, H. Nagashima, J. Org. Chem. 2002, 67, 4985-4988.

[6] a) J. Zheng, S. Chevance, C. Darcel, J.-B. Sortais, Chem. Commun 2013, 49, 10010-10012; b) D. Bézier, S. Park, M. Brookhart, Org. Lett. 2013, 15, 496-499; c) C. Cheng, M. Brookhart, Angew. Chem. Int. Ed. 2012, 51, 9422-9424; d) L. C. Misal Castro, H. Li, J.-B. Sortais, C. Darcel, Chem. Commun. 2012, 48, 10514-10516.

[7] F. J. Fernández-Alvarez, R. Lalrempuia, L. A. Oro, Coord. Chem. Rev 2017, doi: 10.1016/j.ccr.2017.04.011.

[8] R. Lalrempuia, M. Iglesias, V. Polo, P. J. Sanz Miguel, F. J. FernándezÁlvarez, J. J. Pérez-Torrente, L. A. Oro, Angew. Chem. Int. Ed. 2012, 51, 12824-12827.

[9] P. Sangtrirutnugul, T. D. Tilley, Organometallics 2007, 26, 5557-5568.

[10] K. Garcés, R. Lalrempuia, V. Polo, F. J. Fernández-Álvarez, P. GarcíaOrduña, F. J. Lahoz, J. J. Pérez-Torrente, L. A. Oro, Chem. Eur. J. 2016, 22, 14717-14729.

[11] A. Julián, V. Polo, E. A. Jaseer, F. J. Fernández-Alvarez, L. A. Oro, ChemCatChem, 2015, 7, 3895-3912.

[12] A. Julián, V. Polo, F. J. Fernández-Alvarez, L. A. Oro, Catal. Sci. Technol. 2017, 7, 1372-1378.

[13] A. Julián, E. A. Jaseer, K. Garcés, F. J. Fernández-Alvarez, P. GarcíaOrduña, F. J. Lahoz, L. A. Oro, Catal. Sci.Technol. 2016, 6, 4410-4417.

[14] A. Julián, J. Guzmán, E. A: Jaseer, F. J. Fernández-Alvarez, R. Royo, V. Polo, P. García-Orduña, F. J. Lahoz, L. A. Oro, Chem. Eur. J. 2017 23, 11898-11907.

[15] D. Cremer, J. A. Pople, J. Am.Chem. Soc. 1975, 97, 1354-1358.

[16] M. Martín, E. Sola, O. Torres, P. Plou, L. A. Oro, Organometallics 2003. 22, 5406-5417.

[17] a) M. Iglesias, A. Iturmendi, P. J. Sanz Miguel, V. Polo, J. J. PérezTorrente, L. A. Oro, Chem. Commun. 2015, 51, 12431-12434; b) A Iturmendi, N. García, E. A. Jaseer, J. Munárriz, P. J. Sanz Miguel, V. Polo, M. Iglesias, L. A. Oro, Dalton Trans. 2016, 45, 12835-12845. 
[18] M. Prinz, L. F. Veiros, M. J. Calhorda, C. C. Romão, E. Herdtweck, F. E. Kühn, W. A. Herrmann, J. Organomet. Chem. 2006, 691, 4446-4458.

[19] J. Graeupner, T. P. Brewster, J. D. Blakemore, N. D. Schley, J. M. Thomsen, G. W. Brudvig, N. Hazari, R. H. Crabtree, Organometallics 2012, 31, 7158-7164.

[20] S. Michlik, R. Kempe, Nat. Chem. 2013, 5, 140-144.

[21] C. R. Groom, I. K. Bruno, M. P. Lighfoot, S. C. Ward, Acta. Crystallogr. B 2016, 72, 171-179.

[22] http://www.manonthemoontech.com/

[23] K. A. Andrianov, S. A. Igonina, V. I. Sidorov, J. Organomet. Chem. $1977,128,43-55$ compounds 10 e and 10 were identified by GC-MS.
[24] SAINT+, version 6.01: Area-Detector Integration Software, Bruker AXS, Madison, 2001.

[25] R. H. Blessing, Acta Crystallogr. 1995, A51, 33-38; SADABS, Area Detector Absorption Correction Program, Bruker AXS, Madison, WI, 1996.

[26] a) G. M. Sheldrick, Acta Crystallogr. 1990, A46, 467-473; b) G. M. Sheldrick, Acta Crystallogr. 2008, A64, 112-122.

[27] G. M. Sheldrick, Acta Crystallogr. 2015, C71, 3-8.

[28] L. J. Farrugia, J. Appl.Crystallogr. 2012, 45, 849-854. 
Entry for the Table of Contents (Please choose one layout)

Layout 1:

\section{FULL PAPER}

Ir-NSiN species have proven to be efficient catalysts for the dehydrogenative silylation of carboxylic acids

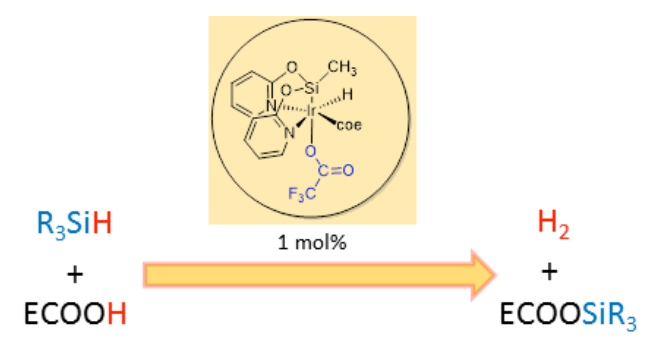

A. Julián, K. Garcés, $R$ Lalrempuia, E. A. Jaseer, $P$. García-Orduña, F. J. FernándezAlvarez, ${ }^{*}$ F. J. Lahoz, ${ }^{[a]}$ and L. A. Oro*

Page No. - Page No.

Reactivity of Ir-NSiN

Complexes: Ir-Catalyzed

Dehydrogenative Silylation of Carboxylic Acids 